\title{
SISTEM PENDUKUNG KEPUTUSAN PEMANGKU JABATAN MENGGUNAKAN PROFILE MATCHING BERBASIS WEB
}

\author{
${ }^{1}$ Randi Triyudanto, ${ }^{2}$ Dedih, ${ }^{3}$ Jajang Mulyana \\ E-mail: ${ }^{1}$ Randi@gmail.com, ${ }^{2}$ dedihthea@gmail.com, ${ }^{3}$ ja2ngm@gmail.com
}

\begin{abstract}
Abstraksi
Proses penempatan pegawai di perusahaan sering kali hanya berdasarkan sedikit faktor, yaitu tingkat pendidikan, lama pengabdian, dan golongan. Terdapat pula perusahaan yang hanya mengandalkan subjektivitas pimpinannya. Oleh karena itu, penulis akan meneliti bagaimana proses menentukan pegawai yang cocok untuk mengisi jabatan dengan mengajukan solusi berupa sistem pendukung keputusan menggunakan profile matching, yaitu sebuah metode yang cara kerjanya dimulai dari menentukan aspek-aspek penilaian, kemudian memetakan selisih (gap) antara profil pegawai dengan profil jabatan, melakukan pembobotan nilai gap, dilanjutkan perhitungan dan pengelompokan core dan secondary factor, menghitung nilai total, hingga tahap yang terakhir adalah perhitungan penentuan ranking. Penelitian ini menggunakan 13 kriteria untuk menilai kinerja pegawai menggunakan sistem kompetensi yang lebih menitikberatkan pada aspek-aspek psikologis. Semakin kecil gap yang dimiliki seorang pegawai, semakin besar peluangnya untuk menempati posisi sebuah jabatan. Hasil akhir proses profile matching adalah ranking pegawai sebagai rekomendasi bagi pengambilan keputusan untuk memilih pegawai yang cocok pada jabatan yang kosong. Kata kunci : sistem pendukung keputusan, pemangku jabatan, profile matching, kinerja pegawai
\end{abstract}

\begin{abstract}
The process of placing employees in companies is often based on a few factors, namely the level of education, length of service, and class. There are also companies that only rely on the subjectivity of their leaders. Therefore, the author will examine how the process of determining employees suitable to fill positions by proposing solutions in the form of decision support systems using profile matching, which is a method that works starting from determining aspects of assessment, then mapping the gap between employee profiles with a position profile, weighting the gap value, followed by calculating and grouping cores and secondary factors, calculating the total value, until the last stage is the calculation of ranking. This study uses 13 criteria to assess employee performance using a competency system that focuses more on psychological aspects. The smaller the gap an employee has, the more likely he is to occupy a position. The final result of the profile matching process is the ranking of employees as recommendations for decision making to select suitable employees in vacant positions The process of placing employees in companies is often based on a few factors, namely the level of education, length of service, and class. There are also companies that only rely on the subjectivity of their leaders. Therefore, the author will examine how the process of determining employees suitable to fill positions by proposing solutions in the form of decision support systems using profile matching, which is a method that works starting from determining aspects of assessment, then mapping the gap between employee profiles with a position profile, weighting the gap value, followed by calculating and grouping cores and secondary factors, calculating the total value, until the last stage is the calculation of ranking. This study uses 13 criteria to assess employee performance using a competency system that focuses more on psychological aspects. The smaller the gap an employee has, the more likely he is to occupy a position. The final result of the profile matching process is the ranking of employees as recommendations for decision making to select suitable employees in vacant positions Keywords: decision support system, position holders, profile matching, employee performance
\end{abstract}




\section{Pendahuluan}

Sistem Pendukung Keputusan (SPK) pada dasarnya merupakan pengembangan lebih lanjut dari Sistem Informasi Manajemen (SIM) yang dirancang sedemikian rupa sehingga memiliki fasilitas interaktif yang dapat mempermudah hubungan antara manusia dengan komputer (Suryadi dan Ramdhani, 2017). Pengertian SPK adalah sistem yang bertujuan untuk menyediakan informasi, membimbing, memberikan prediksi, serta mengarahkan pengguna informasi agar dapat melakukan pengambilan keputusan dengan lebih baik dan berbasis fakta. Secara hierarkis, SPK biasanya dikembangkan untuk pengguna pada tingkatan manajemen menengah dan tertinggi. SPK yang baik harus mampu menggali informasi dari database, melakukan analisis, serta memberikan interprestasi dalam bentuk yang mudah dipahami dengan format yang mudah untuk digunakan (user friendly) (Hartawan, 2007). Dalam organisasi, proses pengambilan keputusan tidak jarang melibatkan banyak pihak, baik dalam lingkungan sendiri maupun lintas fungsional pada area-area lain.

Organisasi yang bergerak di bidang produksi maupun jasa, tidak lepas dari problematika manajemen pada umumnya. Perubahan struktur pasar, produk, teknologi produksi, dan yang lainnya terus terjadi sehingga berpengaruh pada kebijaksanaan manajemen yang dijalankan. Salah satu cara untuk menyiasati problematika tersebut adalah dengan mengembangkan serta meningkatkan potensi sumber daya yang tersedia. Oleh karena itu, penempatan dan pemanfaatan sumber daya pada posisi yang tepat mutlak diperlukan. Dalam hal ini, pengelolaan dan pendayagunaan sumber daya secara tepat sangat berperan karena merupakan suatu pendekatan strategis terhadap peningkatan kinerja organisasi. Menurut (Nawawi, 2010) seringkali proses untuk penempatan pegawai pada posisi jabatan tertentu hanya berdasarkan pada faktor tertentu saja, yaitu tingkat pendidikan, lamanya waktu bekerja, dan golongan. Namun demikian masih terdapat banyak faktor penunjang lain seperti daya tahan, ketekunan, ketelitian, dan keahlian lainnya. Di PT Syapril Janizar hingga saat ini belum memiliki standar baku untuk menentukan pegawai yang akan menempati sebuah jabatan apabila terdapat posisi yang kosong. Proses yang berjalan sejauh ini hanya mengandalkan intuisi para pengambil keputusan sehingga tingkat subjektivitasnya sangat tinggi. Untuk itu sangat diperlukan sebuah sistem untuk mendukung keputusan yang efektif, yang tidak memisahkan antara manusia, sarana/prasarana, dan sistem manajemen secara keseluruhan agar dapat mencapai tujuan organisasi. SPK yang cocok untuk mengatasi masalah di atas adalah menggunakan metode profile matching. Beberapa penelitian terkait pengembangan SPK yang menggunakan metode profile matching pernah dilakukan di antaranya menghasilkan SPK dengan metode profile matching yang dapat meningkatkan akurasi penilaian proposal secara profesional dan proporsional berdasar kriteria penilaian yang telah ditentukan (Faizal, 2014). Selain itu, terdapat juga rancang bangun SPK yang menghasilkan rekomendasi guru yang akan menempati sekolah pilihan penempatan berdasarkan pencocokan profil (Nurdianto dkk., 2016). Terakhir, SPK menggunakan metode profile matching dapat mengatasi keputusan dalam penerimaan calon karyawan yang tidak objektif dan dapat mengatasi kelemahan bagian Sumber Daya Manusia (SDM) yang selama ini membutuhkan waktu lama dan jenuh dalam menyeleksi calon pegawai karena terlalu banyak dokumen calon pegawai yang harus diperiksa (Gunawan dkk., 2016). Dari beberapa hasil penelitian yang telah dilakukan sebelumnya, profile matching terbukti dapat mengatasi permasalahan terkait penempatan individu ke dalam sebuah posisi secara objektif dengan cara mencocokkan profil jabatan dengan profil pegawai untuk memilih kandidat yang paling sesuai untuk suatu jabatan, sehingga dibutuhkan sebuah sistem pendukung keputusan pemangku jabatan menggunakan profile matching berbasis web. Sistem ini dikembangkan menggunakan System Development Life Cycle (SDLC) Waterfall (Satzinger et al, 2010). Adapun model pemrograman yang digunakan adalah pendekatan berorientasi objek atau Object Oriented Approach (OOA), serta bahasa pemrograman PHP dan basisdata MySQL. 


\section{Tinjauan Pustaka}

Menurut Little (1990), "SPK sebagai seperangkat prosedur berbasis model untuk memproses data dan penilaian untuk membantu seorang manajer dalam pengambilan keputusannya. Untuk menjadi sukses, sistem semacam itu harus sederhana, kuat, mudah dikendalikan, adaptif, lengkap pada hal-hal penting, dan mudah untuk berkomunikasi dengannya".

Menurut Kusrini (2007), "profile matching adalah sebuah mekanisme pengambilan keputusan dengan mengasumsikan bahwa terdapat tingkat variabel prediktor yang ideal yang harus dimiliki oleh pegawai, bukan tingkat minimal yang harus dipenuhi atau dilewati. Dalam profile matching, pegawai yang diangkat untuk menempati posisi tertentu adalah pegawai yang paling mendekati profil ideal seorang pegawai yang berhasil".

Menurut (Kadir, (2004), Web adalah program yang menggunakan HTTP sebagai protokol komunikasi dan menyampaikan informasi berbasis web kepada pengguna dalam bentuk HTML dengan menggunakan bahasa pemrograman PHP. PHP adalah kependekan dari Hypertext Preprocessor, bahasa interpreter yang mempunyai kemiripan dengan bahasa $C$ dan Perl yang memiliki kesederhanaan dalam perintah, yang digunakan untuk pembuatan aplikasi web".

SDLC waterfall yaitu suatu metodologi pengembangan perangkat lunak yang mengusulkan pendekatan kepada perangkat lunak sistematik dan sekuensial pada Project Planning Phase, Analysis Phase, Design Phase, Implementation Phase, dan Support Phase (Satzinger dkk., 2010)

\section{Metode Penelitian}

\section{Bahan penelitian}

Bahan penelitian diambil dari studi literatur tentang sistem pendukung keputusan, metode profile matching dan tentang sistem kompetensi pegawai yang digunakan perusahaan untuk mendeskripsikan potensi SDM. Selain itu, penulis juga mencari referensi dari sumber lain, di antaranya melalui jurnal, ebook dan beberapa buku yang sesuai dengan topik penelitian.

\section{SDLC waterfall}

Metode pengembangan sistem yang digunakan SDLC waterfall. Menurut Satzinger SDLC waterfall yang terdiri dari project planning phase, analysis phase, design phase, implementation phase dan support phase.

\section{Analisis Teori SPK}

Pada Empat tahapan SPK menurut (Turban et al., 2007) seperti terlihat pada gambar di bawah ini :

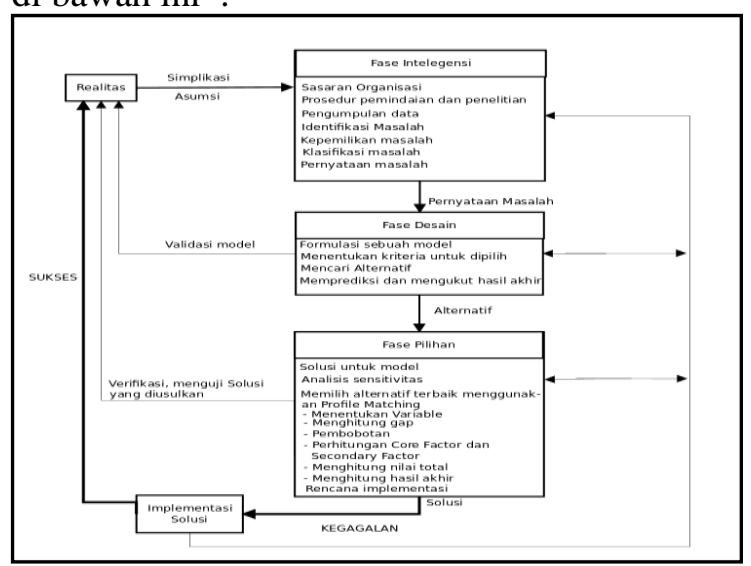

Gambar 1 Tahapan pengembangan SPK

(Turban et al., 2007)

Adapun penjelasannya sebagai berikut :

1. Fase Intelegensi adalah Pengambilan keputusan meliputi scanning (pemindaian) lingkungan yang mencangkup berbagai aktivitas yang menekan identitas situasi atau peluangpeluang masalah.

2. Fase Desain merupakan penemuan atau mengembangkan dan menganalisis tindakan yang mungkin untuk dilakukan, meliputi pemahaman masalah dan menguji solusi yang layak.

3. Fase Pilihan adalah Keputusan yang nyata dan diambil suatu komitmen untuk mengikuti suatu tindakan tertentu. Tahapan dalam metode profile matching yaitu:

a. Menentukan aspek-aspek penilaian

b. Pemetaan gap kompetensi

c. Melakukan pembobotan.

d. Perhitungan dan pengelompokan core factor dan secondary factor 
e. Perhitungan nilai total

f. Perhitungan penentuan ranking

4. Fase Implementasi adalah Solusi yang diusulkan untuk suatu masalah adalah inisialisasi terhadap hal baru atau pengenalan terhadap perubahan.

\section{Hasil Dan Pembahasan}

\section{Hasil Analysis Teori}

1) Analisis Teori Pemangku Jabatan

Tahap analisis teori pemangku jabatan menjelaskan aspek-aspek dan kriteria yang harus dipenuhi seorang pegawai:

a. Kriteria dari aspek intelektual

Adapun yang termasuk dari aspek intelektual adalah verbalisme ide, sistematika berpikir,konsentrasi, logika praktis dan imajinasi berpikir.

b. Kriteria dari aspek sikap kerja

Kriteria dari aspek sikap kerja terdiri energi psikis, ketelitian dan tanggungjawab, kehatihatian, dorongan berprestasi.

c. Kriteria dari aspek perilaku Kriteria dari aspek prilaku terdiri dari Dominance (kekuasaan), Influences (pengaruh), Steadiness (keteguhan hati) dan Compliance (pemenuhan)

\section{Hasil Perhitungan Profil Matching}

Perhitungan dengan menggunakan tahapan metode profile matching dijelaskan sebagai berikut:

1) Menentukan aspek-aspek penilaian Aspek-aspek penilaian telah dijelaskan sebelumnya pada sub-bab analisis teori pemangku jabatan yang terdiri dari 3 aspek dan 13 kriteria.

2) Pemetaan gap dan pembobotan

a. Pemetann gap

Menggunakan rumus:

Gap = Value Atribut - Value Target

Keterangan :

Gap= Selisih kriteria yang dimiliki dengan kriteria target

Value Atribut = Nilai yang dimiliki oleh alternatif
Value Target $=$ Nilai target yang harus dimiliki alternatif

b. Pembobotan

Tabel 1 bobot nilai gap (Kusrini, 2009)

\begin{tabular}{|c|c|c|c|}
\hline No & Selisih & $\begin{array}{l}\text { Bobot } \\
\text { Nilai }\end{array}$ & Keterangan \\
\hline 1 & 0 & 5 & Tidak ada selisih \\
\hline 2 & 1 & 4,5 & $\begin{array}{l}\text { Kompetensi individu } \\
\text { kelebihan } \\
\text { tingkat/level }\end{array}$ \\
\hline 3 & -1 & 4 & $\begin{array}{l}\text { Kompetensi individu } \\
\text { kekurangan } \\
\text { tingkat/level }\end{array}$ \\
\hline 4 & 2 & 3,5 & $\begin{array}{l}\text { Kompetensi individu } \\
\text { kelebihan } \\
\text { tingkat/level }\end{array}$ \\
\hline 5 & -2 & 3 & $\begin{array}{l}\text { Kompetensi individu } \\
\text { kekurangan } \\
\text { tingkat/level }\end{array}$ \\
\hline 6 & 3 & 2,5 & $\begin{array}{l}\text { Kompetensi individu } \\
\text { kelebihan } \\
\text { tingkat/level }\end{array}$ \\
\hline 7 & -3 & 2 & $\begin{array}{l}\text { Kompetensi individu } \\
\text { kekurangan } \\
\text { tingkat/level }\end{array}$ \\
\hline 8 & 4 & 1,5 & $\begin{array}{l}\text { Kompetensi individu } \\
\text { kelebihan } \\
\text { tingkat/level }\end{array}$ \\
\hline 9 & -4 & 1 & $\begin{array}{l}\text { Kompetensi } \\
\text { individu kekurangan } \\
4 \text { tingkat/level }\end{array}$ \\
\hline
\end{tabular}

Tabel 2 Hasil pemetaan gap dan pembobotan kriteria pada Aspek Kapasitas Intelektual

\begin{tabular}{|c|c|c|c|c|c|}
\hline \multirow[t]{2}{*}{ No } & \multirow[t]{2}{*}{ Nama Pegawai } & \multicolumn{4}{|c|}{ Kriteria A } \\
\hline & & VA & VT & $\mathrm{G}$ & B \\
\hline 1 & Cahya Hidayat & 3 & 3 & 0 & 5 \\
\hline 2 & Edi Kurniawan & 3 & 3 & 0 & 5 \\
\hline 3 & $\begin{array}{l}\text { Joko } \\
\text { Suprabowo }\end{array}$ & 2 & 3 & -1 & 4 \\
\hline 4 & $\begin{array}{l}\text { Rianto Sapto } \\
\mathrm{Aji}\end{array}$ & 2 & 3 & -1 & 4 \\
\hline 5 & $\begin{array}{l}\text { Syahrul } \\
\text { Nuzaman }\end{array}$ & 1 & 3 & -2 & 3 \\
\hline 6 & Teguh Sutoro & 3 & 3 & 0 & 5 \\
\hline 7 & Yayan Cahyadi & 4 & 3 & 1 & 4,5 \\
\hline
\end{tabular}

Keterangan:
$\mathrm{VA}=$ Value Atribut
$\mathrm{G} \quad=$ Gap kompetensi
VT =Value Target
$\mathrm{B}=$ Bobot 
Tabel 3 Hasil pemetaan gap dan pembobotan kriteria pada Aspek Kapasitas Intelektual

\begin{tabular}{llllll}
\hline \multirow{2}{*}{ No } & Nama Pegawai & \multicolumn{4}{c}{ Kriteria B } \\
\cline { 3 - 6 } & & VA & VT & G & B \\
\hline 1 & Cahya Hidayat & 3 & 4 & -1 & 4 \\
2 & Edi Kurniawan & 4 & 4 & 0 & 5 \\
3 & Joko & 3 & 4 & -1 & 4 \\
& Suprabowo & & & & \\
4 & Rianto Sapto & 3 & 4 & -1 & 4 \\
& Aji & & & & \\
5 & Syahrul & 1 & 4 & -3 & 2 \\
& Nuzaman & & & & \\
6 & Teguh Sutoro & 3 & 4 & -1 & 4 \\
7 & Yayan Cahyadi & 3 & 4 & -1 & 4 \\
\hline
\end{tabular}

Tabel 4 Hasil pemetaan gap dan pembobotan kriteria pada Aspek Kapasitas Intelektual

\begin{tabular}{llllll}
\hline \multirow{2}{*}{ No } & Nama Pegawai & \multicolumn{4}{c}{ Kriteria C } \\
\cline { 3 - 6 } & & VA & VT & G & B \\
\hline 1 & Cahya Hidayat & 3 & 4 & -1 & 4 \\
2 & Edi Kurniawan & 3 & 4 & -1 & 4 \\
3 & Joko & 4 & 4 & 0 & 5 \\
& Suprabowo & & & & \\
4 & Rianto Sapto & 4 & 4 & 0 & 5 \\
& Aji & & & & \\
5 & Syahrul & 1 & 4 & -3 & 2 \\
& Nuzaman & & & & \\
6 & Teguh Sutoro & 2 & 4 & -2 & 3 \\
7 & Yayan Cahyadi & 4 & 4 & 0 & 5 \\
\hline
\end{tabular}

Tabel 5 Hasil pemetaan gap dan pembobotan kriteria pada Aspek Kapasitas Intelektual

\begin{tabular}{llllll}
\hline \multirow{2}{*}{ No } & Nama Pegawai & \multicolumn{4}{c}{ Kriteria D } \\
\cline { 3 - 6 } & & VA & VT & G & B \\
\hline 1 & Cahya Hidayat & 2 & 3 & -1 & 4 \\
2 & Edi Kurniawan & 2 & 3 & -1 & 4 \\
3 & Joko & 3 & 3 & 0 & 5 \\
& Suprabowo & & & & \\
4 & Rianto Sapto & 3 & 3 & 0 & 5 \\
& Aji & & & & \\
5 & Syahrul & 1 & 3 & -2 & 3 \\
& Nuzaman & & & & \\
6 & Teguh Sutoro & 2 & 3 & -1 & 4 \\
7 & Yayan Cahyadi & 3 & 3 & 0 & 5 \\
\hline
\end{tabular}

Tabel 6 Hasil pemetaan gap dan pembobotan kriteria pada Aspek Kapasitas Intelektual

\begin{tabular}{llllll}
\hline \multirow{2}{*}{ No } & Nama Pegawai & \multicolumn{4}{c}{ Kriteria E } \\
\cline { 3 - 6 } & & VA & VT & G & B \\
\hline 1 & Cahya Hidayat & 4 & 3 & 1 & 4,5 \\
2 & Edi Kurniawan & 4 & 3 & 1 & 4,5 \\
3 & Joko & 2 & 3 & -1 & 4 \\
& Suprabowo & & & & \\
4 & Rianto Sapto & 3 & 3 & 0 & 5 \\
& Aji & & & &
\end{tabular}

\begin{tabular}{llllll}
5 & Syahrul & 1 & 3 & -2 & 3 \\
& $\begin{array}{l}\text { Nuzaman } \\
6\end{array}$ & & & & \\
7 & Teguh Sutoro & 3 & 3 & 0 & 5 \\
Yayan Cahyadi & 3 & 3 & 0 & 5 \\
\hline
\end{tabular}

Tabel 7 Hasil pemetaan gap dan pembobotan kriteria pada Aspek Sikap Kerja

\begin{tabular}{llcccc}
\hline \multirow{2}{*}{ No } & Nama & \multicolumn{5}{c}{ Kriteria F } \\
\cline { 2 - 6 } & Pegawai & VA & VT & G & B \\
\hline 1 & $\begin{array}{l}\text { Cahya } \\
2\end{array}$ & 3 & 3 & 0 & 5 \\
Hidayat & $\begin{array}{l}\text { Edi } \\
3\end{array}$ & 3 & 3 & 0 & 5 \\
Kurniawan & $\begin{array}{l}\text { Joko } \\
\text { Suprabowo }\end{array}$ & 2 & 3 & -1 & 4 \\
5 & $\begin{array}{l}\text { Rianto } \\
\text { Sapto Aji } \\
5\end{array}$ & 2 & 3 & -1 & 4 \\
6 & $\begin{array}{l}\text { Syahrul } \\
\text { Nuzaman } \\
\text { Teguh }\end{array}$ & 1 & 3 & -2 & 3 \\
7 & $\begin{array}{l}\text { Sutoro } \\
\text { Yayan } \\
\text { Cahyadi }\end{array}$ & 5 & 3 & 1 & 4,5 \\
\hline
\end{tabular}

Tabel 8 Hasil pemetaan gap dan pembobotan kriteria pada Aspek Sikap Kerja

\begin{tabular}{|c|c|c|c|c|c|}
\hline \multirow[t]{2}{*}{ No } & \multirow{2}{*}{$\begin{array}{l}\text { Nama } \\
\text { Pegawai }\end{array}$} & \multicolumn{4}{|c|}{ Kriteria $\mathrm{G}$} \\
\hline & & VA & VT & $\mathrm{G}$ & B \\
\hline 1 & $\begin{array}{l}\text { Cahya } \\
\text { Hidayat }\end{array}$ & 2 & 3 & -1 & 4 \\
\hline 2 & $\begin{array}{l}\text { Edi } \\
\text { Kurniawan }\end{array}$ & 4 & 3 & 1 & 4,5 \\
\hline 3 & $\begin{array}{l}\text { Joko } \\
\text { Suprabowo }\end{array}$ & 3 & 3 & 0 & 5 \\
\hline 4 & $\begin{array}{l}\text { Rianto Sapto } \\
\text { Aji }\end{array}$ & 3 & 3 & 0 & 5 \\
\hline 5 & $\begin{array}{l}\text { Syahrul } \\
\text { Nuzaman }\end{array}$ & 1 & 3 & -2 & 3 \\
\hline 6 & Teguh Sutoro & 2 & 3 & -1 & 4 \\
\hline 7 & $\begin{array}{l}\text { Yayan } \\
\text { Cahyadi }\end{array}$ & 3 & 3 & 0 & 5 \\
\hline
\end{tabular}

Tabel 9 Hasil pemetaan gap dan pembobotan kriteria pada Aspek Sikap Kerja

\begin{tabular}{llcccc}
\hline \multirow{2}{*}{ No } & Nama & \multicolumn{5}{c}{ Kriteria H } \\
\cline { 2 - 6 } & Pegawai & VA & VT & G & B \\
\hline 1 & $\begin{array}{l}\text { Cahya } \\
2\end{array}$ & 2 & 3 & -1 & 4 \\
Hidayat & $\begin{array}{l}\text { Edi } \\
\text { Kurniawan }\end{array}$ & 2 & 3 & -1 & 4 \\
4 & $\begin{array}{l}\text { Joko } \\
\text { Suprabowo }\end{array}$ & 3 & 3 & 0 & 5 \\
Rianto Sapto & 4 & 3 & 1 & 4,5 \\
Aji & & & &
\end{tabular}




\begin{tabular}{llllll}
5 & Syahrul & 1 & 3 & -2 & 3 \\
& Nuzaman & & & & \\
7 & Teguh Sutoro & 3 & 3 & 0 & 5 \\
& Yayan & 2 & 3 & -1 & 4 \\
\hline
\end{tabular}

Tabel 10 Hasil pemetaan gap dan pembobotan kriteria pada Aspek Sikap Kerja

\begin{tabular}{|c|c|c|c|c|c|}
\hline \multirow[t]{2}{*}{ No } & \multirow{2}{*}{$\begin{array}{l}\text { Nama } \\
\text { Pegawai }\end{array}$} & \multicolumn{4}{|c|}{ Kriteria I } \\
\hline & & VA & VT & $\mathrm{G}$ & B \\
\hline 1 & $\begin{array}{l}\text { Cahya } \\
\text { Hidayat }\end{array}$ & 3 & 4 & -1 & 4 \\
\hline 2 & $\begin{array}{l}\text { Edi } \\
\text { Kurniawan }\end{array}$ & 4 & 4 & 0 & 5 \\
\hline 3 & $\begin{array}{l}\text { Joko } \\
\text { Suprabowo }\end{array}$ & 3 & 4 & -1 & 4 \\
\hline 4 & $\begin{array}{l}\text { Rianto Sapto } \\
\text { Aji }\end{array}$ & 2 & 4 & -2 & 3 \\
\hline 5 & $\begin{array}{l}\text { Syahrul } \\
\text { Nuzaman }\end{array}$ & 1 & 4 & -3 & 2 \\
\hline 6 & Teguh Sutoro & 1 & 4 & -3 & 2 \\
\hline 7 & $\begin{array}{l}\text { Yayan } \\
\text { Cahyadi }\end{array}$ & 4 & 4 & 0 & 5 \\
\hline
\end{tabular}

Tabel 11 Hasil pemetaan gap dan pembobotan kriteria pada Aspek Prilaku

\begin{tabular}{|c|c|c|c|c|c|}
\hline \multirow[t]{2}{*}{ No } & \multirow{2}{*}{$\begin{array}{l}\text { Nama } \\
\text { Pegawai }\end{array}$} & \multicolumn{4}{|c|}{ Kriteria J } \\
\hline & & VA & VT & $\mathrm{G}$ & $\mathrm{B}$ \\
\hline 1 & $\begin{array}{l}\text { Cahya } \\
\text { Hidayat }\end{array}$ & 2 & 3 & -1 & 4 \\
\hline 2 & $\begin{array}{l}\text { Edi } \\
\text { Kurniawan }\end{array}$ & 2 & 3 & -1 & 4 \\
\hline 3 & $\begin{array}{l}\text { Joko } \\
\text { Suprabowo }\end{array}$ & 3 & 3 & 0 & 5 \\
\hline 4 & $\begin{array}{l}\text { Rianto Sapto } \\
\text { Aji }\end{array}$ & 3 & 3 & 0 & 5 \\
\hline 5 & $\begin{array}{l}\text { Syahrul } \\
\text { Nuzaman }\end{array}$ & 1 & 3 & -2 & 3 \\
\hline 6 & Teguh Sutoro & 4 & 3 & 1 & 4,5 \\
\hline 7 & $\begin{array}{l}\text { Yayan } \\
\text { Cahyadi }\end{array}$ & 4 & 3 & 1 & 4,5 \\
\hline
\end{tabular}

Tabel 12 Hasil pemetaan gap dan pembobotan kriteria pada Aspek Prilaku

\begin{tabular}{llcccc}
\hline \multirow{2}{*}{ No } & Nama & \multicolumn{5}{c}{ Kriteria K } \\
\cline { 2 - 5 } & Pegawai & VA & VT & G & B \\
\hline 1 & $\begin{array}{l}\text { Cahya } \\
2\end{array}$ & 3 & 2 & 1 & 4,5 \\
2 & $\begin{array}{l}\text { Hidayat } \\
\text { Edi }\end{array}$ & 3 & 2 & 1 & 4,5 \\
Kurniawan & $\begin{array}{l}\text { Joko } \\
\text { Suprabowo }\end{array}$ & 2 & 2 & 0 & 5 \\
4 & $\begin{array}{l}\text { Rianto Sapto } \\
\text { Aji }\end{array}$ & 3 & 2 & 1 & 4,5
\end{tabular}

\begin{tabular}{llllcc}
5 & $\begin{array}{l}\text { Syahrul } \\
\text { Nuzaman }\end{array}$ & 1 & 2 & -1 & 4 \\
6 & Teguh Sutoro & 2 & 2 & 0 & 5 \\
7 & Yayan & 3 & 2 & 1 & 4,5 \\
& Cahyadi & & & & \\
\hline
\end{tabular}

Tabel 13 Hasil pemetaan gap dan pembobotan kriteria pada Aspek Prilaku

\begin{tabular}{llcccc}
\multirow{2}{*}{ No } & Nama & \multicolumn{5}{c}{ Kriteria L } \\
\cline { 2 - 6 } & Pegawai & VA & VT & G & B \\
\hline 1 & $\begin{array}{l}\text { Cahya } \\
2\end{array}$ & 3 & 3 & 0 & 5 \\
Hidayat & $\begin{array}{l}\text { Edi } \\
\text { Kurniawan }\end{array}$ & 2 & 3 & -1 & 4 \\
4 & $\begin{array}{l}\text { Joko } \\
\text { Suprabowo } \\
\text { Rianto Sapto }\end{array}$ & 4 & 3 & 0 & 5 \\
5 & $\begin{array}{l}\text { Aji } \\
\text { Syahrul }\end{array}$ & 1 & 3 & -2 & 3 \\
6 & $\begin{array}{l}\text { Nuzaman } \\
\text { Teguh } \\
\text { Sutoro }\end{array}$ & 3 & 3 & 0 & 5 \\
Yayan & 1 & 3 & -2 & 3 \\
Cahyadi & & & & & 4,5 \\
\hline
\end{tabular}

Tabel 14 Hasil pemetaan gap dan pembobotan kriteria pada Aspek Prilaku

\begin{tabular}{llrrrr}
\multirow{2}{*}{ No } & Nama & \multicolumn{5}{c}{ Kriteria M } \\
\cline { 2 - 6 } & Pegawai & VA & VT & G & B \\
\hline 1 & Cahya & 3 & 4 & -1 & 4 \\
2 & $\begin{array}{l}\text { Hidayat } \\
\text { Edi }\end{array}$ & 3 & 4 & -1 & 4 \\
& $\begin{array}{l}\text { Kurniawan } \\
3\end{array}$ & & & & \\
& Joko & 4 & 4 & 0 & 5 \\
4 & $\begin{array}{l}\text { Suprabowo } \\
\text { Rianto Sapto }\end{array}$ & 4 & 4 & 0 & 5 \\
5 & $\begin{array}{l}\text { Aji } \\
\text { Syahrul }\end{array}$ & 1 & 4 & -3 & 2 \\
6 & $\begin{array}{l}\text { Nuzaman } \\
\text { Teguh Sutoro }\end{array}$ & 1 & 4 & -3 & 2 \\
7 & $\begin{array}{l}\text { Yayan } \\
\text { Cahyadi }\end{array}$ & 2 & 4 & -2 & 3 \\
\hline
\end{tabular}

Tabel 15 Pengelompokan Core dan Secondary Factor \begin{tabular}{llll}
\hline No & Aspek & Nilai & \\
\hline 1 & Kapasitas & $20 \%$ & Core Factor :
\end{tabular} Intelektual

(A) Verbalisasi ide,

(B)Sistematika berpikir, (C) Konsentrasi

Secondary Factor 


\begin{tabular}{|c|c|c|c|}
\hline \multirow{4}{*}{2} & & & $\begin{array}{l}\text { (D) Logika } \\
\text { praktis }\end{array}$ \\
\hline & & & $\begin{array}{l}\text { (E)Imajinasi } \\
\text { kreatif }\end{array}$ \\
\hline & $\begin{array}{l}\text { Sikap } \\
\text { kerja }\end{array}$ & $30 \%$ & $\begin{array}{l}\text { Core Factor : } \\
\text { (F)Energi } \\
\text { psikis }\end{array}$ \\
\hline & & & $\begin{array}{l}\text { (G)Ketelitian } \\
\text { dan tanggung } \\
\text { jawab }\end{array}$ \\
\hline \multirow{4}{*}{3} & \multirow{4}{*}{ Perilaku } & \multirow{4}{*}{$50 \%$} & $\begin{array}{l}\text { Secondary } \\
\text { Factor : } \\
\text { (H) Kehati- } \\
\text { hatian, } \\
\text { (I) Dorongan } \\
\text { berprestasi }\end{array}$ \\
\hline & & & $\begin{array}{l}\text { Core Factor } \\
(\mathrm{J}) \text { Dominance } \\
\text { (K)Influences }\end{array}$ \\
\hline & & & $\begin{array}{l}\text { Secondary } \\
\text { Factor : }\end{array}$ \\
\hline & & & $\begin{array}{l}\text { (L) Steadiness } \\
(M) \text { Compliance }\end{array}$ \\
\hline
\end{tabular}

Rumus menghitung Core factor :

$\mathrm{NCF}=\frac{\sum \mathrm{NC}(\mathrm{I}, \mathrm{S}, \mathrm{P})}{\mathrm{m}}$

Rumus menghitung Secondary factor :

$\mathrm{NSF}=\frac{\sum \mathrm{NC}(\mathrm{I}, \mathrm{S}, \mathrm{P})}{\mathrm{n}}$

Keterangan :

$\mathrm{NCF}$ : nilai rata-rata core factor

NSF : nilai rata-rata secondary factor

$\mathrm{NC}(\mathrm{i}, \mathrm{s}, \mathrm{p})$ : Jumlah total nilai core factor yang ada dari aspek intelektual, sikap kerja, dan perilaku.

NS(i,s,p) : Jumlah total nilai secondary factor yang ada dari aspek intelektual, sikap kerja, dan perilaku.

$\mathrm{m}$ : Jumlah item core factor

$\mathrm{n}$ : Jumlah item secondary factor
Contoh perhitungan core factor aspek

kapasitas intelektual untuk pegawai

bernama Cahya Hidayat:

$\mathrm{NCF}=\underline{\text { kriteria } \mathrm{A}+\text { kriteria } \mathrm{B}+\text { kriteria } \mathrm{C}}$ 3

$$
\begin{aligned}
& =\frac{5+4+4}{3} \\
& =13 / 3
\end{aligned}
$$

$\mathrm{NCF}=4,33$

Tabel 16 Pengelompokan Core Factor dan

\begin{tabular}{|c|c|c|c|}
\hline No & $\begin{array}{l}\text { Nama } \\
\text { Pegawai }\end{array}$ & $\begin{array}{l}\text { Core Factor } \\
(\mathrm{A}+\mathrm{B}+\mathrm{C}) / 3\end{array}$ & $\begin{array}{l}\text { Seconday } \\
\text { Factor } \\
(D+E) / 2\end{array}$ \\
\hline 1 & $\begin{array}{l}\text { Cahya } \\
\text { Hidayat }\end{array}$ & 4,33 & 4,25 \\
\hline 2 & $\begin{array}{l}\text { Edi } \\
\text { Kurniawan }\end{array}$ & 4,67 & 4,25 \\
\hline 3 & $\begin{array}{l}\text { Joko } \\
\text { Suprabowo }\end{array}$ & 4,33 & 4,5 \\
\hline 4 & $\begin{array}{l}\text { Rianto } \\
\text { Sapto Aji }\end{array}$ & 4,33 & 5 \\
\hline 5 & $\begin{array}{l}\text { Syahrul } \\
\text { Nuzaman }\end{array}$ & 2,33 & 3 \\
\hline 6 & $\begin{array}{l}\text { Teguh } \\
\text { Sutoro }\end{array}$ & 3,83 & 4,75 \\
\hline 7 & $\begin{array}{l}\text { Yayan } \\
\text { Cahyadi }\end{array}$ & 4,33 & 4 \\
\hline
\end{tabular}
Secondary Factor Aspek Kapasitas Intelektual

Tabel 17 Pengelompokan Core Factor dan Secondary

\begin{tabular}{|c|c|c|c|}
\hline No & $\begin{array}{l}\text { Nama } \\
\text { Pegawai }\end{array}$ & $\begin{array}{l}\text { Core Factor } \\
(\mathrm{F}+\mathrm{G}) / 2\end{array}$ & $\begin{array}{l}\text { Seconday } \\
\text { Factor } \\
(\mathrm{H}+\mathrm{I}) / 2\end{array}$ \\
\hline 1 & $\begin{array}{l}\text { Cahya } \\
\text { Hidayat }\end{array}$ & 4,5 & 4 \\
\hline 2 & $\begin{array}{l}\text { Edi } \\
\text { Kurniawan }\end{array}$ & 4,75 & 4,5 \\
\hline 3 & $\begin{array}{l}\text { Joko } \\
\text { Suprabowo }\end{array}$ & 4,5 & 4,5 \\
\hline 4 & $\begin{array}{l}\text { Rianto } \\
\text { Sapto Aji }\end{array}$ & 4,5 & 3,75 \\
\hline 5 & $\begin{array}{l}\text { Syahrul } \\
\text { Nuzaman }\end{array}$ & 3 & 2,5 \\
\hline 6 & $\begin{array}{l}\text { Teguh } \\
\text { Sutoro }\end{array}$ & 4,25 & 3,5 \\
\hline 7 & $\begin{array}{l}\text { Yayan } \\
\text { Cahyadi }\end{array}$ & 4,25 & 4,5 \\
\hline
\end{tabular}
Factor Aspek Sikap Kerja 
Rumus perhitungan nilai total

$$
\mathrm{NT}=(\mathbf{x}) \% \mathrm{NCF}+(x) \% \mathrm{NSF}
$$

Keterangan :

$\mathrm{NCF}$ : Nilai rata-rata core factor

NSF : Nilai rata-rata secondary factor

NT : Nilai total dari aspek $(\mathrm{x}) \%$ : Nilai persen yang di-input

Contoh menghitung nilai total aspek kapasitas intelektual (N(i)) untuk pegawai bernama Cahya Hidayat:

$$
\begin{aligned}
\mathrm{N}(\mathrm{i}) & =(60 \% \times 4,33333)+(40 \% \times 4,25) \\
& =4,3
\end{aligned}
$$

\begin{tabular}{|c|c|c|c|c|}
\hline \multirow[t]{2}{*}{ No } & \multirow{2}{*}{$\begin{array}{l}\text { Nama } \\
\text { Pegawai }\end{array}$} & \multicolumn{3}{|c|}{ NT (i) } \\
\hline & & $\mathrm{CF}(60 \%)$ & $\mathrm{SF}(40 \%)$ & NT \\
\hline 1 & $\begin{array}{l}\text { Cahya } \\
\text { Hidayat }\end{array}$ & 4,33 & 4,25 & 4,3 \\
\hline 2 & $\begin{array}{l}\text { Edi } \\
\text { Kurniawan }\end{array}$ & 4,67 & 4,25 & 4,5 \\
\hline 3 & $\begin{array}{l}\text { Joko } \\
\text { Suprabowo }\end{array}$ & 4,33 & 4,5 & 4,4 \\
\hline 4 & $\begin{array}{l}\text { Rianto } \\
\text { Sapto Aji }\end{array}$ & 4,33 & 5 & 4,6 \\
\hline 5 & $\begin{array}{l}\text { Syahrul } \\
\text { Nuzaman }\end{array}$ & 2,33 & 3 & 2,6 \\
\hline 6 & $\begin{array}{l}\text { Teguh } \\
\text { Sutoro }\end{array}$ & 3,83 & 4,75 & 4,2 \\
\hline 7 & $\begin{array}{l}\text { Yayan } \\
\text { Cahyadi }\end{array}$ & 4,33 & 4 & 4,7 \\
\hline
\end{tabular}

Tabel 18 Hasil perhitungan nilai total Intelektual

Keterangan :

$\mathrm{SF}=$ Nilai rata-rata Core Factor

$\mathrm{CF}=$ Nilai rata-rata Secondary Factor

NT $=$ Nilai Total

NT(i) = Nilai Total Aspek Kapasitas Intelektual

NT(s) = Nilai Total Aspek Sikap Kerja

\begin{tabular}{|c|c|c|c|c|}
\hline \multirow[t]{2}{*}{ No } & \multirow{2}{*}{$\begin{array}{l}\text { Nama } \\
\text { Pegawai }\end{array}$} & \multicolumn{3}{|c|}{ NT (s) } \\
\hline & & $\mathrm{CF}(60 \%)$ & $\mathrm{SF}(40 \%)$ & NT \\
\hline 1 & $\begin{array}{l}\text { Cahya } \\
\text { Hidayat }\end{array}$ & 4,5 & 4 & 4,3 \\
\hline 2 & $\begin{array}{l}\text { Edi } \\
\text { Kurniawan }\end{array}$ & 4,75 & 4,5 & 4,65 \\
\hline 3 & $\begin{array}{l}\text { Joko } \\
\text { Suprabowo }\end{array}$ & 4,5 & 4,5 & 4,5 \\
\hline 4 & $\begin{array}{l}\text { Rianto } \\
\text { Sapto Aji }\end{array}$ & 4,5 & 3,75 & 4,2 \\
\hline 5 & $\begin{array}{l}\text { Syahrul } \\
\text { Nuzaman }\end{array}$ & 3 & 2,5 & 2,8 \\
\hline
\end{tabular}

NT $(\mathrm{P})=$ Nilai Total Aspek Perilaku

Tabel 19 Hasil perhitungan nilai total Sikap Kerja

\begin{tabular}{|c|c|c|c|c|}
\hline \multirow[t]{2}{*}{ No } & \multirow{2}{*}{$\begin{array}{l}\text { Nama } \\
\text { Pegawai }\end{array}$} & \multicolumn{3}{|c|}{ NT (p) } \\
\hline & & $\mathrm{CF}(60 \%)$ & $\mathrm{SF}(40 \%)$ & NT \\
\hline 1 & $\begin{array}{l}\text { Cahya } \\
\text { Hidayat }\end{array}$ & 4,25 & 4,5 & 4,35 \\
\hline 2 & $\begin{array}{l}\text { Edi } \\
\text { Kurniawan }\end{array}$ & 4,25 & 4 & 4,15 \\
\hline 3 & $\begin{array}{l}\text { Joko } \\
\text { Suprabowo }\end{array}$ & 5 & 5 & 5 \\
\hline 4 & $\begin{array}{l}\text { Rianto } \\
\text { Sapto Aji }\end{array}$ & 4,75 & 4,75 & 4,75 \\
\hline 5 & $\begin{array}{l}\text { Syahrul } \\
\text { Nuzaman }\end{array}$ & 3,5 & 2,5 & 3,1 \\
\hline 6 & $\begin{array}{l}\text { Teguh } \\
\text { Sutoro }\end{array}$ & 4,75 & 3,5 & 4,25 \\
\hline 7 & $\begin{array}{l}\text { Yayan } \\
\text { Cahyadi }\end{array}$ & 4,5 & 3 & 3,9 \\
\hline
\end{tabular}

\begin{tabular}{clccr}
6 & Teguh & 4,5 & 4 & 4,3 \\
& Sutoro & 4,25 & 4,5 & 4,35 \\
7 & Yayan & & & \\
\hline
\end{tabular}

Tabel 20 Hasil perhitungan nilai total aspek perilaku

Rumus untuk menghitung ranking adalah:

$(\mathrm{x}) \% \mathrm{NT}(\mathrm{i})+(\mathrm{x}) \% \mathrm{NT}(\mathrm{s})+(\mathrm{x}) \% \mathrm{NT}(\mathrm{p})$

Keterangan :

NT (i): : Nilai Kapasitas Intelektual

NT (s) : Nilai Sikap Kerja

NT (p) : Nilai Perilaku

\begin{tabular}{|c|c|c|c|c|}
\hline \multirow[t]{2}{*}{ No } & \multirow{2}{*}{$\begin{array}{l}\text { Nama } \\
\text { Pegawai }\end{array}$} & \multirow{2}{*}{$\begin{array}{l}\text { NT (i) } \\
20 \% \\
\end{array}$} & \multirow{2}{*}{$\begin{array}{c}\mathrm{NT}(\mathrm{s}) \\
30 \% \\
\end{array}$} & \multirow{2}{*}{$\begin{array}{r}\mathrm{NT}(\mathrm{p}) \\
50 \% \\
\end{array}$} \\
\hline & & & & \\
\hline 1 & $\begin{array}{l}\text { Cahya } \\
\text { Hidayat }\end{array}$ & 4,3 & 4,3 & 4,35 \\
\hline 2 & $\begin{array}{l}\text { Edi } \\
\text { Kurniawan }\end{array}$ & 4,5 & 4,65 & 4,15 \\
\hline 3 & $\begin{array}{l}\text { Joko } \\
\text { Suprabowo }\end{array}$ & 4,4 & 4,5 & 5 \\
\hline 4 & $\begin{array}{l}\text { Rianto } \\
\text { Sapto Aji }\end{array}$ & 4,6 & 4,2 & 4,75 \\
\hline 5 & $\begin{array}{l}\text { Syahrul } \\
\text { Nuzaman }\end{array}$ & 2,6 & 2,8 & 3,1 \\
\hline 6 & $\begin{array}{l}\text { Teguh } \\
\text { Sutoro }\end{array}$ & 4,2 & 3,95 & 4,25 \\
\hline 7 & $\begin{array}{l}\text { Yayan } \\
\text { Cahyadi }\end{array}$ & 4,7 & 4,35 & 3,9 \\
\hline
\end{tabular}

(x)\% : Nilai persentase setiap aspek

Tabel 21 Hasil akhir ranking pegwai

Jurnal Interkom: Jurnal Publikasi Ilmiah Bidang Teknologi Informasi dan Komunikasi

Volume 14 Nomor 02 Bulan Juli - Tahun 2019 


\begin{tabular}{|c|c|c|c|}
\hline No & $\begin{array}{c}\text { Nama } \\
\text { Pegawai }\end{array}$ & Total & Rangking \\
\hline 1 & $\begin{array}{l}\text { Cahya } \\
\text { Hidayat }\end{array}$ & 4,32 & 4 \\
\hline 2 & $\begin{array}{l}\text { Edi } \\
\text { Kurniawan }\end{array}$ & 4,37 & 3 \\
\hline 3 & $\begin{array}{l}\text { Joko } \\
\text { Suprabowo }\end{array}$ & 4,73 & 1 \\
\hline 4 & $\begin{array}{l}\text { Rianto } \\
\text { Sapto Aji }\end{array}$ & 4,55 & 2 \\
\hline 5 & $\begin{array}{l}\text { Syahrul } \\
\text { Nuzaman }\end{array}$ & 2,91 & 7 \\
\hline 6 & $\begin{array}{l}\text { Teguh } \\
\text { Sutoro }\end{array}$ & 4,15 & 6 \\
\hline 7 & $\begin{array}{l}\text { Yayan } \\
\text { Cahyadi }\end{array}$ & 4,19 & 5 \\
\hline
\end{tabular}

\section{Kesimpulan dan Saran}

\section{Kesimpulan}

Berdasarkan pembahasan maka dapat ditarik kesimpulan yaitu proses penilaian kinerja pegawai dapat menggunakan sistem kompetensi yang lebih menitikberatkan pada aspek-aspek psikologis yang terdiri dari 3 aspek dan 13 kriteria. Adapun nilai target yang ditetapkan perusahaan untuk hasil perhitungan dari seluruh aspek adalah 3,25. Hasil akhir menunjukkan terdapat 3 pegawai yang menempati ranking tertinggi, yaitu Joko Suprabowo, Rianto Sapto Aji, dan Edi Kurniawan yang direkomendasikan untuk mengisi posisi jabatan baru yang telah ditentukan.

\section{Saran}

Rekomendasi untuk mendapatkan hasil yang lebih baik, penulis menyarankan agar penelitian berikutnya dapat memadukan profile matching dengan metode lainnya sehingga diharapkan pegawai yang dinilai dapat dikategorikan bukan hanya layak dan tidak layak, tetapi dapat dikategorikan secara lebih detail.

\section{Daftar Pustaka}

Faizal, Edi. 2014. Implementasi Metode Profile Matching Untuk Penentuan Penerimaan Usulan Penelitian Internal Dosen Stmik El Rahma. Jurnal Sentra Penelitian Engineering dan Edukasi Volume 6 No 1. ISSN: 2088- 0154

Galin, Daniel. 2004. Software Quality Assurance. Pearson Addison Wesley. Gunawan, Halim, Fandi, Purba, Raimon Perdana. 2016. Pengembangan SPK

Penerimaan Karyawan Menggunakan Profile Matching (Studi Kasus: PT X). Seminar Nasional Teknologi Informasi dan Multimedia. ISSN: 2302- 3805.

Handojo dkk. 2003. Pembuatan Aplikasi Sistem Pendukung Keputusan Untuk Proses Kenaikan Jabatan dan Perencanaan Karir Pada PT X. Jurnal Informatika. 4(2):98106. ISSN: 2528-5823.

Hartawan, Urip Indra. 2007. Sistem Pendukung Keputusan Pemilihan Penerima Beasiswa dengan menggunakan Logika Fuzzy Metode Tsukamoto. Yogyakarta: Universitas Islam Indonesia.

Kadir, Abdul. 2014. Pengenalan Sistem Informasi Edisi Revisi. Penerbit Andi: Yogyakarta.

Kusrini. 2007. Konsep dan Aplikasi Sistem Pendukung Keputusan. Penerbit Andi: Yogyakarta.

Manan, Bagir. 2004. Teori dan Politik Konstitusi. Yogyakarta: FH UII Press. Muqtadir, Asfan, Dan Purdianto, Irwan. 2013. Sistem Pendukung Keputusan

Kenaikan Jabatan Menggunakan Metode Profile Matching (Studi Kasus PT

Industri Kemasan Semen Gresik). Seminar Nasional Aplikasi Teknologi Informasi (SNATI). ISSN: 1907-5022.

Nawawi, Hadari. 2010. Manajemen Sumber Daya Manusia untuk Bisnis yang Kompetitif. Yogyakarta (ID): UGM Press.

Nurdianto, Agus, Hartati, Sulis Janu, Maulana, Yoppy Mirza. 2016. Rancang Bangun Sistem Pendukung Keputusan Penempatan Tenaga Pendidik Menggunakan Metode Profile Matching. Jurnal Sistem Informasi dan Komputer 
Akuntansi (JSIKA) Vol. 5 No. 2. ISSN: 2338-137X.

Satzinger, John W., Jackson, Robert B., Burd, Stephen D. 2010. System Analysis and Design in a Changing World, Fourth Edition, Thomson Course Technology. Cananda. ISBN-10: 1-4239-0228-9.

Simarmata, Janner. 2010. Rekayasa Web. Penerbit Andi: Yogyakarta.

Suryadi, Kadarsah, dan Ramdhani, Ali. 2017. Sistem Pendukung Keputusan. Bandung (ID): Rosda.

Turban, Efraim, Aronson, Jay E., Liang, TingPeng. 2007. Decision Support Systems and Intelligent Systems. Prentice Hall: New Delhi. ISBN: 978-81- 203-2961-4 